\title{
Surgical Treatment of Grisel Syndrome: A Pediatric Case Report and Review of the Literature
}

\author{
Ali Börekci, Erhan Çelikoğlu
}

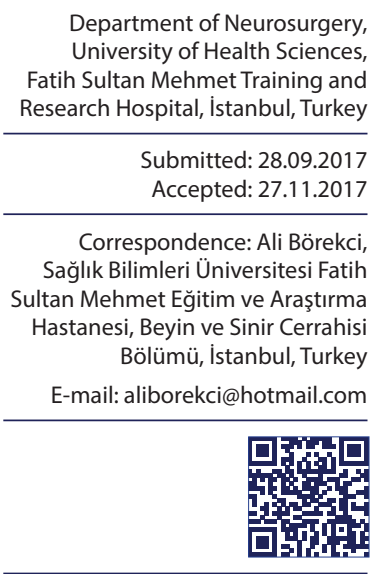

Keywords: Grisel syndrome; pediatric; surgical intervention.

\begin{abstract}
Spontaneous subluxation of the atlantoaxial joint secondary to inflammatory head and neck conditions is defined as Grisel syndrome, and is usually seen in children. The primary treatment is conservative. Delayed diagnosis and treatment can result in a painful and persistent cervical deformity, and may require surgical treatment. In this report, the case of a I4-yearold patient who presented with spontaneous atlantoaxial rotatory subluxation after adenotonsillectomy is described. When no reduction was obtained with conservative treatment, surgical intervention was performed.
\end{abstract}

\section{INTRODUCTION}

Spontaneous subluxation of the atlantoaxial joint following nasopharyngeal inflammation is known as Grisel syndrome. It is most frequently related to head and neck infections, such as pharyngitis, adenotonsillitis, tonsillar abscess, cervical abscess, or otitis media, and it may develop following otorhinolaryngological interventions, such as a tonsillectomy, adenoidectomy, or a mastoidectomy. Radiological examinations are valuable in the management of subluxation of the atlantoaxial joint. If diagnosed at an early stage, the primary treatment of Grisel syndrome is conservative. If reduction cannot be achieved with conservative treatment, then surgical treatment may be required. ${ }^{[1]}$

In this report, a I4-year-old male patient treated with for a diagnosis of Grisel syndrome is discussed in the light of the literature.

\section{CASE REPORT}

A 14-year-old male patient presented at the emergency service with the complaint of the sudden onset of a stiff neck and restricted neck movement when he got out of bed in the morning I week after an adenotonsillectomy operation performed with monopolar cautery and bipolar cautery for hemostasis. A physical examination revealed painful and limited neck movement and the head rotated to the right. A neurological examination indicated that he was fully conscious and cooperated with normal balance coordination, normoactive deep tendon reflexes, normal sphincter reflexes, and had no motor or sensory deficit.

In the first phase of treatment, given that the patient had no history of trauma, he was given antibiotics, a muscle relaxant, and anti-inflammatory treatment, and was discharged with a cervical collar and scheduled for a return visit 3 weeks later. At the control examination, it was observed that the torticollis, a rightward rotation of the head, and painful and restricted neck movement persisted. The patient underwent a 3-dimensional (3D) cervical computed tomography (CT) examination, and atlantoaxial rotatory subluxation was detected. The diagnosis of Grisel syndrome was made in a clinical consultation, and 
cervical traction was applied. On the fifth day of traction, a cervical $X$-ray demonstrated successful reduction, and a halo-vest was used to immobilize the patient. Three months later, the halo-vest was removed and substituted with a cervical collar, with a control visit planned for I week later.

At the follow-up appointment, his neck movements were still restricted and painful, and his head was still tilted to the right, but with no neurological deficit. His 3D CT examination was repeated, and in addition to atlantoaxial rotatory subluxation (Fig. Ia, b, and d), it was observed that the atlanto-odontoid distance was $5.5 \mathrm{~cm}$ (Fig. Ic). Since all conservative treatment methods had failed, surgery $(\mathrm{CI}$ lateral mass-C2 pedicular fixation) was planned.

The patient was brought into the operating room in the prone position with a neuromonitor in place. Following occipital Cl-C2 subperiostal dissection, screws were implanted in the bilateral C2 pedicle (Fig. 2c) and the right $\mathrm{Cl}$ lateral mass (Fig. 2b) under fluoroscopy. As a result of perioperative rotation of the arch of the atlas (Fig. Ib), a deeply situated left lateral mass, and technical difficulties in the placement of the screws, the stabilization system was extended to the occipital region (Fig. 2a), and the left posterior arch of the atlas was pulled outward with a sublaminar wire (Fig. 2b) to achieve reduction and anchored to the rod. With this maneuver, occipitocervical fixation was achieved. Autogenous bone grafts excised from the posterior iliac wing were used for posterolateral fusion before termination of the surgery.

Postoperative CT images revealed achievement of complete reduction (Fig. $2 \mathrm{~d}$ and e). The patient's pain was decreasing and he was discharged without any problem and a prescription for a cervical collar.

\section{DISCUSSION}

Spontaneous subluxation of the atlantoaxial joint developing secondary to inflammatory processes in the head and neck is known as Grisel syndrome. ${ }^{[1]}$ Various pathogenic hypotheses have been described. Osiro et al. ${ }^{[2]}$ reported
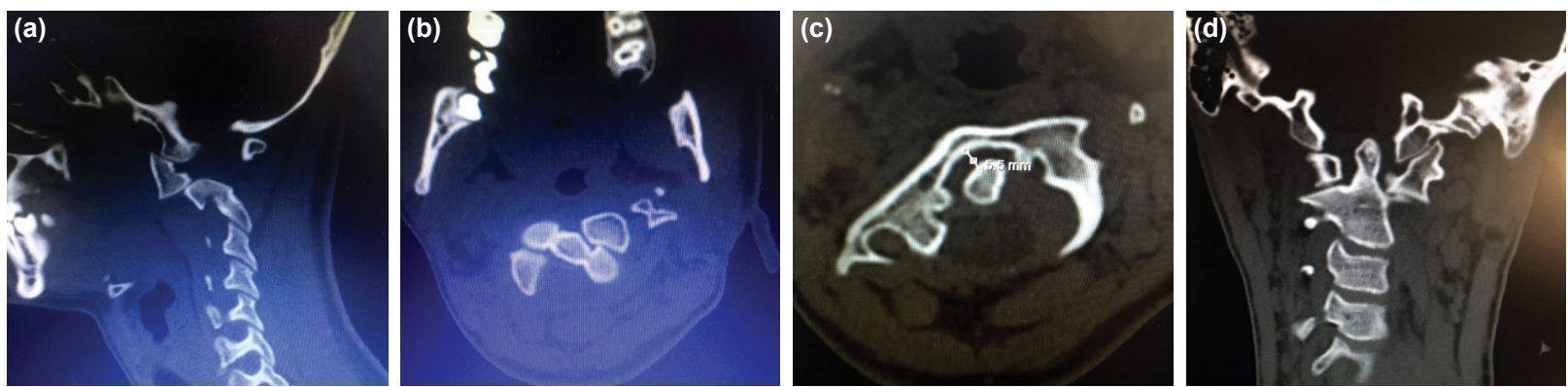

Figure 1. (a) Preoperative sagittal cervical computed tomography (CT). (b) Preoperative axial cervical CT. (c) Atlanto-odontoid distance. (d) Preopreative coronal cervical CT.
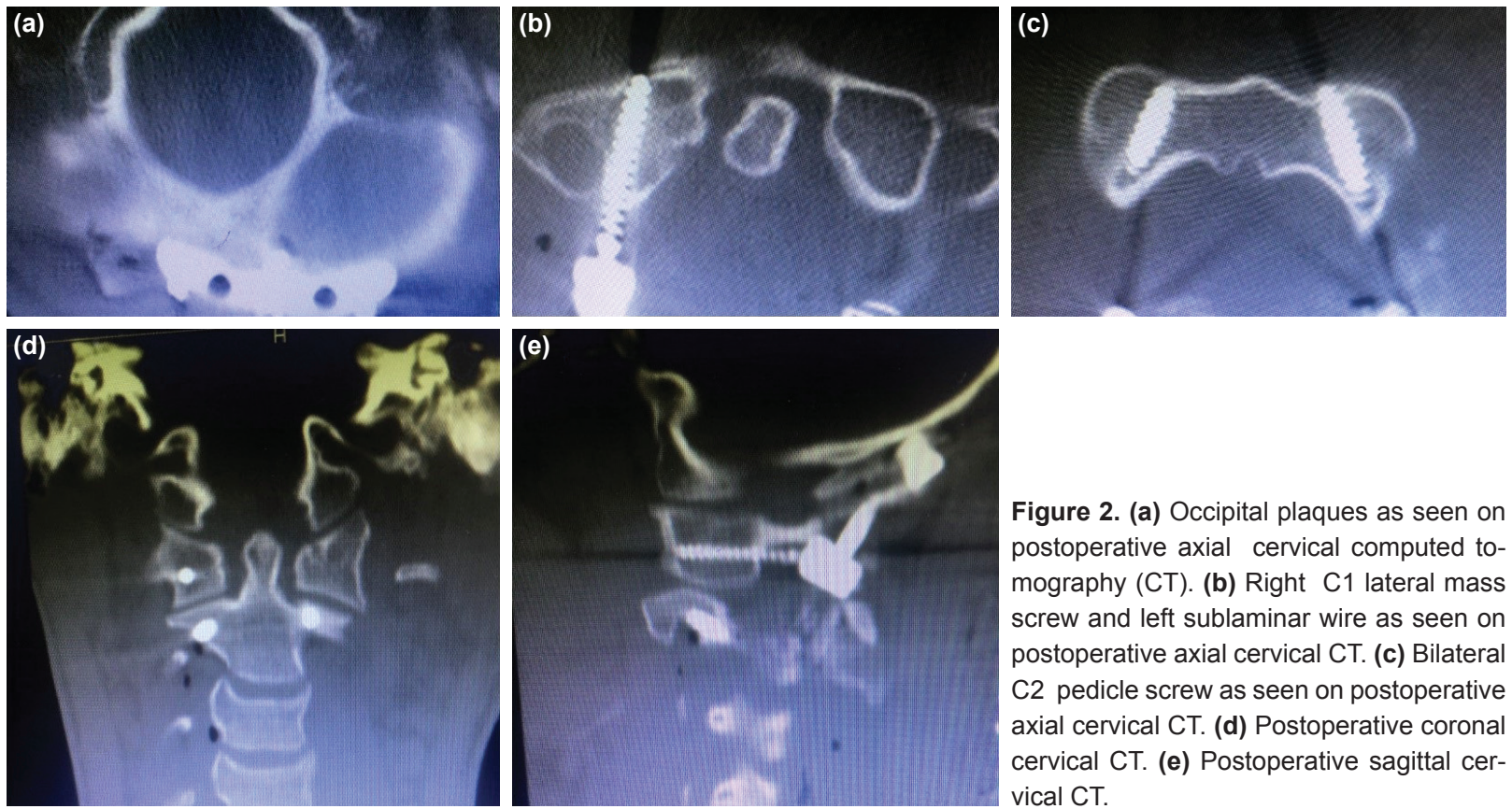

Figure 2. (a) Occipital plaques as seen on postoperative axial cervical computed tomography (CT). (b) Right C1 lateral mass screw and left sublaminar wire as seen on postoperative axial cervical CT. (c) Bilateral C2 pedicle screw as seen on postoperative axial cervical CT. (d) Postoperative coronal cervical CT. (e) Postoperative sagittal cervical CT. 
that peripharyngeal septic effusion may be transported by the hematogenous route via anastomoses between the periodontoid venous plexus and pharyngovertebral vessels to the atlantoaxial ligaments, with a resultant laxity in both the transverse and alar ligaments. ${ }^{[2]}$ Ahn et al. ${ }^{[3]}$ reported that inflammatory changes in the atlantoaxial joint may lead to the development of Grisel syndrome without ligament laxity. ${ }^{[3]}$ Pathogenic agents of this syndrome have also occasionally been identified. The isolation of Fusobacterium necrophorum, beta-hemolytic Streptococci, Pseudomonas aeruginosa, Staphylococcus aureus, methicillinresistant Staphylococcus epidermidis, the Epstein-Barr virus, and Mycobacterium tuberculosis have been reported in cases of Grisel syndrome. ${ }^{[4]}$ The vast majority of cases occur in children and young adults; $68 \%$ of reported cases are under 12 years of age and $90 \%$ are under 21 years of age. ${ }^{[5]}$ Grisel syndrome may present with torticollis, cervical pain, tinnitus, and limited, painful neck movement. ${ }^{[6]}$

In Grisel syndrome, the diagnosis of atlantoaxial subluxation requires a thorough neuroradiological examination, including the use of ordinary $\mathrm{X}$-rays, CT imagery, and magnetic resonance imaging $(\mathrm{MRI})$. The best visualization of this pathology is realized using $3 D C T$. MRI is a complementary radiological tool, and may reveal abnormalities of the soft tissues and neural structures, and laxity in the transverse and alar ligaments. ${ }^{[7]}$

Table I. Fielding and Hawkins classification of nontraumatic atlantoaxial joint subluxation

\begin{tabular}{ll}
\hline Type & Atlantoaxial rotatory subluxation \\
\hline Type I & $\begin{array}{l}\text { Rotatory subluxation of atlas without anterior } \\
\text { displacement }\end{array}$ \\
Type 2 & $\begin{array}{l}\text { Rotatory dislocation and minimal }(<5 \mathrm{~mm}) \\
\text { anterior displacement of atlas }\end{array}$ \\
Type 3 & $\begin{array}{l}\text { Rotatory dislocation and }>5 \mathrm{~mm} \text { anterior } \\
\text { displacement of atlas }\end{array}$ \\
Type 4 & $\begin{array}{l}\text { Rotatory subluxation of atlas with posterior } \\
\text { displacement }\end{array}$ \\
\hline
\end{tabular}

Fielding and Hawkins ${ }^{[8]}$ divided non-traumatic subluxation of atlantoaxial joint into 4 types (Table I). In our case, in addition to atlantoaxial dislocation, the atlanto-odontoid distance was measured at $5.5 \mathrm{~mm}$, and evaluated as Fielding type 3. Most frequently, type I and type 2 subluxations are seen, which do not include neurological deficits. Type 3 and type 4 subluxations may be associated with spinal cord compression and severe neurological deficits. ${ }^{[1]}$ Fielding type I and type 2 subluxations may be treated with antibiotics and a cervical collar; however, in some patients, the use of a cervical collar or a halo-vest for 6 weeks after initial cervical traction may be required to prevent recurrence of subluxation. In cases with Fielding type 3 and type 4 subluxations, cervical traction, bed rest, and subsequent cervical immobilization are required. ${ }^{[6]}$

Surgical treatment is applied if conservative treatment fails and symptoms worsen. Techniques such as occipitocervical fixation, wiring with $\mathrm{Cl}-\mathrm{C} 2$ bone graft (BrooksJenkins fusion), transarticular atlantoaxial screw (Magerl technique), and $\mathrm{Cl}$ lateral mass with $\mathrm{C} 2$ transpedicular screw and rod (Harms-Goel technique) have been used to provide reduction and fixation in cases with $\mathrm{Cl}-\mathrm{C} 2$ instability. ${ }^{[9]}$ Since we couldn't achieve satisfactory reduction as a result of conservative treatment, we pursued surgical treatment. We found 9 cases with Grisel syndrome in the literature managed with posterior cervical arthrodesis (Table 2). There was I case each of $\mathrm{Cl}$ laminar hook and C2 pedicle screw, ${ }^{[9]}$ Harms-Goel $\mathrm{Cl}$ lateral mass and C2 pedicle screw technique, ${ }^{[10]}$ occipitocervical fixation and wiring, ${ }^{[1]} 5$ instances of sublaminar wiring and $\mathrm{Cl}-\mathrm{C} 2$ interspinous allograft, ${ }^{[12]}$ and I case of $\mathrm{Cl}-\mathrm{C} 2$ transarticular screw and $\mathrm{Cl}$ lateral mass screw. ${ }^{[13]}$

Tschopp ${ }^{[14]}$ reported that monopolar suction cautery is a risk factor for the development of Grisel syndrome after adenoidectomy. If intensive hemostasis is required during a surgical procedure, then prophylactic antibiotherapy should be considered. Forceful passive neck rotation and extreme hyperextension of the neck under general anesthesia should be avoided to prevent this potential postoperative complication. ${ }^{[15]}$

Table 2. Cases of Grisel syndrome in the literature that were surgically treated

\begin{tabular}{lcccl}
\hline Author & Year & Cases (n) & Patient age (years) & Surgery performed \\
\hline Lee & 2002 & 5 & 7-12, median: 9 & $\mathrm{Cl}-\mathrm{C} 2$ sublaminar wiring \\
Yamazaki & 2008 & $\mathrm{I}$ & 26 & Occipitocervical fixation and wiring \\
Desai & 2010 & 1 & 9 & Fixation using $\mathrm{Cl}$ lateral mass screw and $\mathrm{C} 2$ transpedicular screw and rod \\
Pereira & 2010 & $\mathrm{I}$ & 66 & Fixation using $\mathrm{Cl}-\mathrm{C} 2$ transarticular screw and $\mathrm{Cl}$ lateral mass screw \\
Morales & 2016 & $\mathrm{I}$ & 5 & Fixation using bilateral $\mathrm{Cl}$ laminar hook and $\mathrm{C} 2$ pedicle screw \\
\hline
\end{tabular}




\section{Conclusion}

Grisel syndrome should be considered in the differential diagnosis of cases with complaints of neck pain and torticollis that developed after head and neck infections or and otorhinolaryngological interventions, and particularly pediatric cases. If conservative treatment fails, surgery should be performed.

\section{Informed Consent}

Approval was obtained from the patients' parents.

Peer-review

Internally peer-reviewed.

Authorship Contributions

Surgical and Medical Practices: A.B., E.Ç.; Concept: A.B., E.Ç.; Design: A.B., E.Ç.; Data collection \&/or processing: A.B.; Analysis and/or interpretation: A.B., E.Ç.; Literature search: A.B.; Writing: A.B.; Critical review: A.B., E.Ç.

Conflict of Interest

None declared.

\section{REFERENCES}

1. Dagtekin A, Kara E, Vayisoglu Y, Koseoglu A, Avci E, Talas D, et al. The importance of early diagnosis and appropriate treatment in Grisel's syndrome: report of two cases. Turk Neurosurg 2011;21:680-4.

2. Osiro S, Tiwari KJ, Matusz P, Gielecki J, Tubbs RS, Loukas M. Grisel's syndrome: a comprehensive review with focus on pathogenesis, natural history, and current treatment options. Childs Nerv Syst 2012;28:821-5. [CrossRef]

3. Ahn AR, Park YH, Park EJ, Yim SY. A Case of Grisel Syndrome Showing No Underlying Laxity of the Atlanto-axial Joint. Ann Rehabil Med 2017;41:511-5. [CrossRef]

4. Lee JK, Oh CH, Park HC, Yoon SH. Grisel's Syndrome Induced by
Mycobacterium tuberculosis. Korean J Spine 2015;12:84-7.

5. Kerolus M, Jeans EB, Fontes RB, Deutsch H, Traynelis VC. Atlantoaxial instability of inflammatory origin in adults: case reports, literature review, and rationale for early surgical intervention. Neurosurgery 2015;76:E226-32. [CrossRef]

6. Spennato $\mathrm{P}$, Nicosia G, Rapanà A, Cicala D, Donnianni T, Scala S, et al. Grisel Syndrome Following Adenoidectomy: Surgical Management in a Case with Delayed Diagnosis. World Neurosurg 2015;84:1494.e7-12. [CrossRef]

7. Fernández Cornejo VJ, Martínez-Lage JF, Piqueras C, Gelabert A, Poza M. Inflammatory atlanto-axial subluxation (Grisel's syndrome) in children: clinical diagnosis and management. Childs Nerv Syst 2003;19:342-7. [CrossRef]

8. Çiftdemir NA, Eren T, Çiftdemir M. A Rare Cause of Torticollis: Grisel Syndrome. Journal of Tropical Pediatrics 2017:1-4.

9. Morales LC, Alvarado F, Corredor JA, Rodríguez A. Bilateral C1 laminar hooks combined with $\mathrm{C} 2$ pedicle screw fixation in the treatment of atlantoaxial subluxation after Grisel syndrome. Spine J 2016;16:e755-60. [CrossRef]

10. Desai R, Stevenson CB, Crawford AH, Durrani AA, Mangano FT. C-1 lateral mass screw fixation in children with atlantoaxial instability: case series and technical report. J Spinal Disord Tech 2010;23:474-9. [CrossRef]

11. Yamazaki M, Someya Y, Aramomi M, Masaki Y, Okawa A, Koda M. Infection-related atlantoaxial subluxation (Grisel syndrome) in an adult with Down syndrome. Spine (Phila Pa 1976) 2008;33:E156-60.

12. Lee SC, Lui TN, Lee ST. Atlantoaxial rotatory subluxation in skeletally immature patients. Br J Neurosurg 2002;16:154-7. [CrossRef]

13. Pereira EA, Hempenstall J, Pretorius PM, Kamat AA, Cadoux-Hudson TA. La maladie de Grisel treated by combined C1-2 transarticular and C1 lateral mass screw fixation. Br J Neurosurg 2010;24:499501. [CrossRef]

14. Tschopp K. Monopolar electrocautery in adenoidectomy as a possible risk factor for Grisel's syndrome. Laryngoscope 2002;112:1445-9.

15. Bocciolini C, Dall'Olio D, Cunsolo E, Cavazzuti PP, Laudadio P. Grisel's syndrome: a rare complication following adenoidectomy. Acta Otorhinolaryngol Ital 2005;25:245-9.

\section{Grisel Sendromunda Cerrahi Tedavi: Pediyatrik Olgu Sunumu ve Literatür Taraması}

Baş ve boyun enflamatuvar süreçlerine sekonder olarak gelişen atlanto-aksiyal eklemin spontan subluksasyonu Grisel sendromu olarak bilinir ve çoğunlukla çocuklarda görülür. Primer tedavisi konservatiftir. Gecikmiş tanı ve tedavi, ağrılı ve kalıcı servikal deformiteye neden olabilir hatta cerrahi tedavi gerektirebilir. Bu yazıda, I4 yaşında adenotonsillektomi operasyonu sonrası spontan atlanto-aksiyal rotatuvar subluksasyon saptanan ve konservatif tedaviler ile redüksiyon sağlanamayıp cerrahi uygulanan hasta literatür eşliğinde tartışıldı.

Anahtar Sözcükler: Cerrahi girişim; Grisel sendromu; pediyatrik. 